Бойко Христина Степанівна, кандидат архітектури, доцент кафедри дизайну та основ архітектури Національного університету «Львівська політехніка» https://orcid.org/0000-0002-4889-8337 khrystyna.boyko@ hotmail.com

\title{
ЕПІТАФІЇ ДАВНІХ ЮДЕЙСЬКИХ КЛАДОВИЩ СХІДНОЇ ГАЛИЧИНИ ЯК ДЖЕРЕЛО ДЛЯ ІСТОРИЧНИХ ТА МИСТЕЦЬКИХ СТУДІЙ
}

Мета роботи - проаналізувати структуру традиційної єврейської епітафії, висвітлити особливості компонування текстів різної складності, охарактеризувати їх зв'язок із символікою меморіальної пластики фасадів мацев Східної Галичини XVI - першої третини XX ст. Методологія дослідження передбачає застосування низки методів: порівняльного, формально-стилістичного, структурно-типологічного. Для аналізу композиційних схем використано мистецтвознавчі категорії, а також практичний досвід візуального, стилістичного, морфологічно-композиційного та комплексного аналізу. Наукова новизна полягає у тому, що вперше детально досліджено структуру традиційної єврейської епітафії, визначено основні принципи побудови композиційних схем текстів різної складності, окреслено їх значення та місце у композиційному вирішенні фасадів галицьких мацев. Оригінальні, представлені у статті тексти епітафій та їх переклад, публікуються вперше. Висновки. Автором проаналізовано структуру традиційної єврейської епітафії, описано іiї призначення, структуру та зміст. Виявлено, що функцію епітафії визначають іiі структурні елементи. Запропоновано методику наукового опрацювання текстів різної складності та охарактеризовано їх зв'язок із символікою меморіальної пластики фасадів мацев. Визначено, що епітафії давніх юдейських кладовищ Східної Галичини XVI - першої третини XX ст. є надзвичайно цінним джерелом для проведення історичних досліджень та мистецьких студій.

Ключові слова: мацева, епітафія, текст, інформація, формула, шрифтова композиція, різьба, пам’ятка.

Бойко Кристина Степановна, кандидат архитектуры, доцент кафедрь дизайна и основ архитектуры Национального университета «Львовская политехника»

Эпитафии древних иудейских кладбищ Восточной Галиции как источник для исторических и художественных студий.

Цель работы - проанализировать структуру традиционной еврейской эпитафии, описать особенности компоновки текстов различной сложности, охарактеризовать их связь с символикой мемориальной пластики фасадов мацев Восточной Галиции XVI - первой трети XX в. Методология исследования предполагает применение ряда методов: сравнительного, формально-стилистического, структурно-типологического. Для анализа композиционных схем использовано искусствоведческие категории, а также практический опыт визуального, стилистического, морфологически-композиционного и комплексного анализа. Научная новизна заключается в том, что впервые подробно исследована структура традиционной еврейской эпитафии, определены основные принципы построения композиционных схем текстов различной сложности, определены их значения и место в композиционном решении фасадов галицких мацев. Оригинальные, представленные в статье тексты эпитафий и их перевод, публикуются впервые. Выводы. Автором проанализирована структура традиционной еврейской эпитафии, описаны ее назначение, структура и содержание. Выявлено, что функцию эпитафии определяют ее структурные элементы. Предложена методика научной проработки текстов различной сложности и охарактеризованы их связь с символикой мемориальной пластики фасадов мацев. Определено, что эпитафии древних иудейских кладбищ Восточной Галиции XVI - первой трети XX в. является чрезвычайно ценным источником для проведения исторических исследований и художественных студий.

Ключевые слова: мацева, эпитафия, текст, информация, формула, шрифтовая композиция, резьба, достопримечательность.

Boyko Khrystyna, Ph.D. in Architecture, Associate Professor of the Department of Design and Fundamentals of Architecture of Lviv Polytechnic National University studies

The epitaph of the ancient Judaic cemeteries of Eastern Galicia as a source for historical and artistic

The purpose of the article is to analyze the structure of the traditional Jewish epitaph, to highlight the peculiarities of the compilation of texts of varying complexity, to characterize their connection with the symbolism of the memorial plastic facades of the mitzvahs of the Eastern Galicia of XVI - the first third of the XX century. The

(C) Бойко X.С., 2019 
methodology of the study involves the use of several methods: comparative, formal-stylistic, structural-typological. For analysis of composite schemes, art criticism categories, as well as practical experience of visual, stylistic, morphological-compositional, and sophisticated analysis, are used. The scientific novelty is that the structure of the traditional Jewish epitaph was first studied in detail, the basic principles of constructing composite schemes of texts of varying complexity were determined, their significance and place in the compositional resolution of the facades of the Galician mitzvahs were outlined. The original texts of the epitaphs and their translations, introduced in the article, are published for the first time. Conclusions. The author analyzes the structure of the traditional Jewish epitaph, describes its purpose, structure, and content. It is discovered that the function of the epitaph is determined by its structural elements. The method of scientific elaboration of texts of various complexity is offered, and their connection with the symbols of the memorial plastic of the faces of the mitzvahs is described. It is determined that the epitaph of the ancient Judaic cemeteries of Eastern Galicia XVI - the first third of the XX century is a valuable source for historical research and artistic studies.

Key words: mitzvah, epitaph, text, information, formula, font composition, carving, memorial.

Актуальність теми дослідження. У Східній Європі, та в Галичині зокрема, на сьогодні налічується декілька мільйонів єврейських надгробків, що дійшли до нас, часто перенесені 3 їхніх оригінальних локацій та часто сильно пошкоджених. Незважаючи на зростаюче зацікавлення, цей предмет ще досі дуже недостатньо вивчений: лише декілька окремих цвинтарів описано чи систематично задокументовано i вивчено. Особливо актуальним завданням $є$ проведення архітектурних обмірів та інвентаризація пам'ятників.

Аналіз досліджень і публікацій. Стаття грунтується на матеріалах багаторічних натурних досліджень автора. Це дослідження стало результатом інтенсивної роботи автора 3 єврейськими епіграфічних пам'ятниками Східної Галичини, до яких відносяться насамперед написи на єврейських надгробках. Розроблена автором методика наукового опрацювання текстів епітафій була апробована під час реалізації дослідницького проекту [1], результати якого висвітлені у працях [2,3]. Дослідженню юдейських епітафій присвячено чимало наукових праць. Так, Б. Хаймович детально аналізує іконографію та семантику рельєфів мацев, здійснює порівняльний аналіз єврейських мотивів iз подібними зображеннями в західноєвропейському та східному мистецтві [12]. У працях [6,7, 8, 9] M. Носоновський детально описує епітафії мацев, символізм написів, визначає особливості композиційних побудов. Написи на предметах з колекції юдаїки досліджує М. Мартин [5,10]. Однак, невисвітленими залишаються провідні осередки та майстри єврейського каменерізного мистецтва. Поза увагою науковців залишилася також низка галицьких кладовищ. Заслуговують окремого грунтовного дослідження різьблені шрифтові композиції фасадів мацев, аналіз типології, художніх особливостей, мистецьких взаємовпливів, техніка нанесення епітафій, що побутувала на теренах Східної Галичини XVI-першої третини XX ст.

Метою дослідження є проаналізувати структуру традиційної єврейської епітафії, висвітлити особливості компонування текстів різної складності, охарактеризувати їх зв'язок із символікою меморіальної пластики фасадів мацев Східної Галичини XVI - першої третини XX ст.

Виклад основного матеріалу. Одним із основних структурних елементів вирішення композиції фасаду мацеви є шрифтова композиція - епітафія, яка є багатообіцяючим джерелом для історичних та мистецьких студій і міститься, як правило у її нижній секції. С три аспекти, у контексті яких можливим $\epsilon$ їх здійснення: перший - пов'язаний з історичною значимістю артефактів, другий - 3 художньо-мистецькою цінністю кам'яної різьби, третій - 3 аналізом та науковим опрацюванням текстів епітафій як літературних творів. Тому для проведення комплексних наукових досліджень юдейських кладовищ слід залучати фахівців різних галузей: археологів, істориків, мистецтвознавців, епіграфістів, талмудистів, етнологів, філологів, фольклористів, інших. Зчитування та розшифрування текстів епітафій має специфічні труднощі, особливо, якщо йдеться про єврейське кладовище. Опрацювання текстів відбувається, як правило, певними етапами, а саме: відтворення тексту вручну 3 мацеви (зчитування, переписування 3 каменю); уточнення зазначеної інформації із документальними матеріалами діяльності єврейської громади ${ }^{1}$.

Більшість епітафій містять характеристики, що підкреслюють зв’язок людини із юдейською духовною традицією. Здебільшого текст епітафії, корелює та суттєво доповнює, тлумачить символіку кам'яної різьби верхньої частини мацеви. Іноді символічне зображення над епітафією не було безпосередньо пов'язане з текстовою інформацією, мало виключно декоративне значення та містило

\footnotetext{
1 Наприклад: приватними архівами; документальними архівними матеріалами діяльності громади - свідоцтвами про народження, одруження, смерть членів єврейської громади; пінкасами, у яких поховальне братство зазначало дату смерті, дату проведення поховальної церемонії.
} 
традиційні юдейські символи чи знаки. Певний мотив міг традиційно використовуватися виключно для декорування надгробків певного сімейства і міг не пов'язуватися із конкретною померлою особою .

Разом із вишуканим оздобленням верхньої секції мацеви та вкритими рослинними орнаментами декоративними бордюрами, що їх обрамлюють, вони утворюють цілісні орнаментальні композиції, які є цінними пам'ятками каменерізного мистецтва та меморіальної пластики давніх юдейських Східної Галичини XVI - першої третини XX ст.

Найстаріша епітафія Східної Свропи, що збереглась у Буську Львівської області датується 1520 р. Переважна більшість цінних текстів збережених до сьогодні мацев датовані кінцем XVIII серединою XIX, більш стандартних та уніфікованих - першою третиною XX ст.

Розглянемо детальніше структуру традиційної єврейської епітафії. У текстах епітафій XVIXIX століть можна виокремити чотири основні невід'ємні елементи та кілька додаткових. До основних належать: 1- вступна формула; 2-ім'я похованого; 3 - дата; 4 - благословення. Розширена епітафія, окрім чотирьох перерахованих елементів, включає: 5 - формули вихваляння померлого, що підкреслюють праведність, богобоязливість, благодійність; 6 -вирази скорботи і горя близьких померлого; 7 - вираз впевненості у відродження мертвих в прийдешні месіанські часи.

Таким чином, тексти епітафій нижньої секції фасаду мацеви можуть бути простими i стандартними або складними і великими за об'ємом та змістом поданої в них інформації. Тексти укладались за певною схемою, чи «формулою». Всі вони містять основну інформацію: ім'я померлого, ім'я його батька (рідше - діда, прадіда), дату смерті за єврейським календарем (рідко дату похорону), іноді доповнену короткою інформацією про найзнаковіші події із життя людини. Дата смерті могла бути умисно прихованою у самому тексті епітафії. Починаючи 3 доби середньовіччя єврейські епітафії містять також дату смерті в якості обов'язкового елемента. Зазначення дати служить практичної мети: дати можливість родичам відзначати річницю смерті. Разом 3 цим причиною зазначення дати було і прагнення прив'язати померлого до єврейської «системи координат» - певної дати на часовій осі і періоду календарного циклу. Кожен текст завершувався виразом: «нехай буде його (ii) душа зав’язана у вузлі життя». Наприклад:

\begin{tabular}{|c|c|}
\hline $\begin{array}{l}\text { Оригінальний текст епітафії: } \\
\text { (на івриті) - фасад }\end{array}$ & $\begin{array}{l}\text { Переклад по рядках } \\
\text { (українською): }\end{array}$ \\
\hline 1. תרמז & 1. $647(1887$ p. $)$ \\
\hline 2. פ"פ & 2. тут похований \\
\hline 3יש תם ו"י & 3. чоловік непорочний і чесний \\
\hline 4. שנתן לחמו לדל & 4. який давав хліб свій бідним \\
\hline 5. מוה משולם & 5. учитель наш рев Мешулєм \\
\hline 6. במוה שלום & 6. син учителя нашого рева Шльоми \\
\hline 7. 7פ כי ניסן & 7. помер 22 нісана (субота, 16 квітня) \\
\hline 8. ת'נ'צ'ב'ה & 8. нехай буде душа його зав’язана у вузлі життя \\
\hline
\end{tabular}

Складні тексти можуть містити інші уточнюючі відомості про місце народження (походження) та вік померлого, сімейний стан, статус у громаді, рід занять, а також вказувати на причину чи обставини смерті померлої особи. Крім того, вони є цінними джерелами історичної інформації, яка стосується багатьох аспектів із життя тогочасної єврейської громади міста чи містечка: професії, майнового стану, історичних подій краю. Наприклад:

\begin{tabular}{|c|c|}
\hline 1. נפ יום יט & 1. помер дня 19 \\
\hline 2. ניסן תרנ & 2. нісана 650 (середа, 9 квітня 1890 р.) \\
\hline 3. פיש הרופה איש & 3. тут похований лікар чоловік \\
\hline 4. מבראדי יצחק & 4. 3 Бродів Їцхак \\
\hline 5. אייזיק המכונה & 5. Айзек по кличці \\
\hline 6. בעער ב" מו"ה & 6. Беер син учителя нашого рева \\
\hline 7. 'בנימין ת'נ'צ'ב'ה & 7. Бен'яміна нехай буде душа його зав'язана у вузлі життя \\
\hline 8. Dr. Isak Beer. & 8. Др. Ісак Беер \\
\hline 9. 9. IV. 1890. & 9. 9. IV. 1890. \\
\hline
\end{tabular}

\begin{tabular}{|c|c|}
\hline תרמז ה" אייר . תרמ & 1. 6475 іяра (п’ятниця, 29 квітня 1887 р.) \\
\hline 2. • יפ איש תם וי & 2. помер чоловік непорочний і чесний \\
\hline 3. מו"ה ראובן ב" & 3. учитель наш рев Реувен син \\
\hline
\end{tabular}




\begin{tabular}{|c|c|}
\hline 4. מו • מענדיל מגזע & 4. учителя нашого Менделя з роду \\
\hline 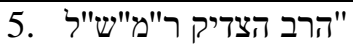 & 5. рева цадика Рамшаля \\
\hline 6. 'מסאסיב ת'נ'צ'ב'ה & 6. з Сасова нехай буде душа його зав'язана у вузлі життя \\
\hline
\end{tabular}

\begin{tabular}{|c|c|}
\hline 1. שושנה באבה ימי & 1. троянда прийшли іiі дні \\
\hline 2. נקטפה אם עניים & 2. була зірвана / мати бідних \\
\hline 3. ואחות אביונים & 3. і сестра неімущих \\
\hline 4. מלחמה נתנה לדל & 4. боролась давала убогому \\
\hline 5. צנועה וחסידה ישרה & 5. скромна і благочестива чесна \\
\hline 6. 6. ותמומה מרת בילא & 6. і непорочна марат (пані) Байля \\
\hline 7. מכפר שדשקאוויץ ב" & 7. зі села Шішковіц донька \\
\hline 8. מו"ה יוסף זאב נספה & 8. вчителя нашого рев Йосеф Зеев / прилучена \\
\hline אל עמי • כ"ד בחודש.9. & 9. до народу свого 24 [дня] в місяці \\
\hline 10. שבט ת'נ'צ'ב'ה' תרמה & $\begin{array}{l}\text { 10. шват (понеділок, } 9 \text { лютого) нехай буде душа їі зав'язана у } \\
\text { вузлі життя } 645 \text { (1885 р.) }\end{array}$ \\
\hline
\end{tabular}

\begin{tabular}{|c|c|}
\hline 1. נפיש תם וישר & 1. помер чоловік непорочний і чесний \\
\hline 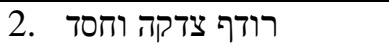 & 2. послідовник справедливості і милості \\
\hline 3. נחמד ואהוב לבריות & 3. милий і любимий у людей \\
\hline 4. יראת ה" זרחה על פניו & 4. який боявся бога сіяння на обличчі його \\
\hline 5. 5גול ומפואר במעלותיו & 5. видатний і прекрасний в достоїнстві своєму \\
\hline 6. נפטר בשם טוב מו"ה & 6. помер в імені доброму вчитель наш рев \\
\hline 7. מאיר ב"ר אברהם מרדכי & 7. Меїр син рева Аврагама Мордехая \\
\hline 8. יא ניסן שנת תרסא & 8. 11 нісана року 661 (неділя, 31 березня 1901 р.) \\
\hline בשלשים לימו חייו.9 & 9. в тридцять років життя його \\
\hline 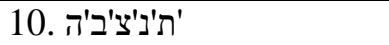 & 10. нехай буде душа його зав’язана у вузлі життя \\
\hline
\end{tabular}

\begin{tabular}{|c|c|}
\hline 1. פנ הבחור החתן & 1. тут покоїться юнак зять \\
\hline 2. כמ"ר פנחס זליג & 2. шанований учитель наш рев Пінхас Зеліг \\
\hline 3. ב" מו"ה שמעון & 3. син учителя нашого рева Сімеона \\
\hline 4. תרנג יג מנחם אב & 4. 65313 менахема ава (середа, 26 липня 1893 р.) \\
\hline 5. פה במעון האבל שמה ושא יה & $\begin{array}{l}\text { 5. тут в обителі трауру спустошення і терпіння [призначене] } \\
\text { богом }\end{array}$ \\
\hline 6. & $\begin{array}{l}\text { 6. похований поклониться досконалому? який помер дружина } \\
\text { його }\end{array}$ \\
\hline 7. חמל על חייו אשר טבע במים & 7. жаль над життям його котре потонуло у воді \\
\hline סר לחלצי ונטבען שנים 8. & 8. не зміг врятуватись і потонули роки \\
\hline זאת תכנה למזכרת ולאות & 9. ця [мацева] встановлена на пам'ять і в знак \\
\hline 10. על אשר ררחיב בנפשו עוז & 10. про рева великого (широкого) в душі якого сила \\
\hline להציל חברו מן גלי עוז .11 & 11. спасіння / союз його з потоком (енергією) сили \\
\hline 12. יהיה לו עתה הציון הלז & 12. буде йому тепер знак цей \\
\hline 13. גל הזה עד והמצבה הזאת - 13 & 13. груда ця свідчить і мацева ця \\
\hline 14. & 14. нехай буде душа його зав'язана у вузлі життя \\
\hline
\end{tabular}

Розширені епітафії містять: конкретні біблійні цитати, звороти із Талмуду, пристосовані до імені померлого, що суттєво утруднює розшифрування інформації; лігатури; знаки, нетипові скорочення - абревіатури; оригінальні поетичні вставки, часто виконані у складній віршованій формі, які у фонетичній транскрипції мають надзвичайно мелодійне звучання. Наприклад: «шамеах бехелько вемода / мошіа вейоец вепода / хазак рецуцім бекехо / геенік оведім мімехо». Специфікою складних текстів поетичного характеру є також те, що в них після або перед обов'язковою стандартною інформацією про покійного, передається характеристика позитивних якостей людини, перелічені моральні якості та чесноти, всі ії достоїнства, надаючи конкретній мацеві особливої індивідуальності. Наприклад:

\begin{tabular}{|l|l|}
\hline 1. & 1. \\
\hline 2. & помер 16 тевета (субота, 12 січня) \\
\hline
\end{tabular}




\begin{tabular}{|c|c|}
\hline לפרט משה עלה אל אלהים בליל טז . & 3. цей Моше зійшов до бога в ночі 16 тевета \\
\hline 4. יזכור & 4. пам'ятатиме \\
\hline 5. אלהים נשמת & 5. бог душу \\
\hline 6. ה]ב]חור כהלכה & 6. юнака який помер \\
\hline 7. בן יקיר הנחמד החריף & 7. син дорогий милий дотепний \\
\hline 8. הנזכר בספר שמחת החג & 8. згаданий в книзі «Сімхат га-Хаг» («Радість свята») \\
\hline 9. יראת ה' זרחה על פניו & 9. боявся бога світло на обличчі його \\
\hline משכיל שלשלת היוחסין .10 & 10. $з$ інтелігентного роду \\
\hline דגול ומפואר במעלותיו .11 & 11. видатний і чудовий в достоїнствах своїх \\
\hline משה דוב בהרב מו"ה .12 & 12. Моше Дов син рева вчителя нашого рева \\
\hline חיים בהרה"ג מקוטב נ"י .13 & 13. Хаїма сина рева gаона з Кутів нехай світить його свіча \\
\hline 14. נכד הרה"ק המחבים & 14. нащадок рева святого автора \\
\hline 15. ספר תפארת ישראל & 15. книги «Тіферет Ïсраель» («Красота Їсраеля») \\
\hline 16. וספר רביד הזהב זצ"ל & $\begin{array}{l}\text { 16. а також книги «Равід га-захав» («Золоте намисто») нехай } \\
\text { пам'ять праведника буде благословенна }\end{array}$ \\
\hline 17. & 17. нехай буде душа його зав'язана у вузлі життя \\
\hline
\end{tabular}

\begin{tabular}{|c|c|}
\hline 1. כד • אדר תרן הלך למנוחות & 1. 28 адара 650 (четвер, 20 березня 1890 р.) відійшов у покій \\
\hline 2. הישיש הנכבד איש תם וישר & 2. старець шанований чоловік непорочний і чесний \\
\hline 3. & 3. учитель наш рев Сгуда син рева Мордехая мир йому \\
\hline 4. ימיו הקדיש לעבודת בוראו & 4. дні його посвячені в роботі творення \\
\hline 5ולך מישרים בצדקתו ואמונתו & 5. ходив прямо в праведності своїй та вірі своїй \\
\hline 6. וישרתו יעודו כל בני דורו & $\begin{array}{l}\text { 6. і справедливості своїй призначенням усіх синів покоління } \\
\text { його }\end{array}$ \\
\hline 7. דרכו פעולתו יצאו ללדותו & $\begin{array}{l}\text { 7. образ його створене ним продовження (виведення) його в } \\
\text { народженому ним }\end{array}$ \\
\hline 8. איש ישר הלך נאסף לעמיו & 8. чоловік прямо ходивший був піднятий до народу свого \\
\hline 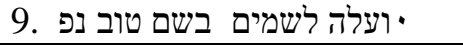 & 9. в імені доброму помер і піднявся в небо \\
\hline 10. נדבת ידיו עם צדקת מעשיו & 10. подавав рукою своєю народу пожертву від праці своєї \\
\hline מדברים בשער בין החיים .11 & 11. говорять у воротах серед живих \\
\hline רבים הילילו מרה לעומתו .12 & 12. багато оплакують його / гіркота в народу його \\
\hline דרכיו כאשר זכרו וטובותיו .13 - ד 13 & 13. дорога його котру пам’ятають і доброта його \\
\hline 14. כבוד עשו לו במותו וקבורתו & 14. честь роблять йому / в смерті його і похороні його \\
\hline 15. יתומים אשר גדל בטוב מדיתיו & 15. сироти [ми] котрого велич у доброті віри його \\
\hline 16. היביתינית & 16. нехай буде душа його зав’язана у вузлі життя \\
\hline
\end{tabular}

\begin{tabular}{|c|c|}
\hline 1. פנ & 1. тут похований \\
\hline 2. תרם יט תמוז & 2. 64019 тамуза (понеділок, 28 червня 1880 р.) \\
\hline 3. ויקרבו ימי ישראל למות & 3. і наблизився час Їсраелю померти \\
\hline 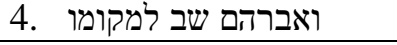 & 4. і Аврагам повернувся у місце своє \\
\hline 5. הילילו כל בית ישראל & 5. оплакуватиме його весь дім Їсраеля \\
\hline 6. 6. וזעקת שבר יעוררו על & 6. і крик біди піднімуть за \\
\hline 7. גבר חכם בעוז ולמד דעת & 7. мужчиною розумним в силі і навчаючогося мудрості \\
\hline 8. את העם ותורה יבקשו & 8. народу і тори / просили \\
\hline 9. מפיהו ובא השמש בצהרים & 9. у нього і приходило сонце о півдні \\
\hline 10.10. ולבז שנים עלה השמים & 10. і соколом роки піднялись на небо \\
\hline 11. ואינינו הה איש חסיד & 11. і не маємо ми шанованого пана чоловіка благочестивого \\
\hline 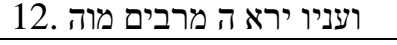 & 12. і скромного який боявся бога робив багато \\
\hline ישראל אברהם ב"מו"ה.13 & 13. Їсраель Аврагам син вчителя нашого рева \\
\hline 14. יצחק אייזיק הלוי זללה & $\begin{array}{l}\text { 14. Їцхака Айзека Галєві нехай пам'ять його буде } \\
\text { благословенна в бога }\end{array}$ \\
\hline 15. & 15. нехай буде душа його зав'язана у вузлі життя \\
\hline
\end{tabular}




\begin{tabular}{|c|c|}
\hline 2. ה אייר תרמה & 2. 5 іяра 645 (20 квітня 1885 р.) \\
\hline 3. אבל גדול כבד בישראל & 3. скорбота велика тяжка в Їсраелі \\
\hline 4. בכו בכיה לשבר הגדול & 4. плачте слізно в біді великій \\
\hline 5. בקול יללה ובמספר מר & 5. в голосі ридання і розповіді гіркота \\
\hline 6. על המרומם מגזעי יוחס & 6. про величного з роду знаного \\
\hline 7. מו חיים בן ברוך בנימין עה & 7. вчитель Хаїм син Баруха Беняміна мир йому \\
\hline 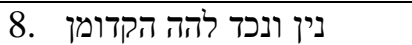 & 8. правнук і нащадок для життя прийдешнього світу древнього \\
\hline בעהמ באר מים חיים זצל.9 & $\begin{array}{l}\text { 9. автора «Беер маїм хаїм» («Колодязя води життя») нехай } \\
\text { буде пам'ять праведника благословенна }\end{array}$ \\
\hline 10. כל שורה לפרט תנצב & $\begin{array}{l}\text { 10. кожний рядок [якої?] на рахунку [в бога?]? нехай буде душа } \\
\text { його зав’язана у вузлі }\end{array}$ \\
\hline $11 . \pi$ & 11. життя \\
\hline
\end{tabular}

В окремих випадках, якщо текст епітафії був розширеним, містив довгі біблійні цитати та тексти поетичного характеру, віршовані вставки або іншу важливу інформацію, яку неможливо було передати за допомогою символічного зображення на верхній секції мацеви, текст повністю покривав всю площину фасаду надгробка. 3 тильного боку мацеви могла міститися інформація, що дублювала основну інформацію або іiі окремі елементи, представлені на фасаді, а саме: ім'я померлої особи та ім'я її батька, рідше додатково зазначена інформація про місце народження, надзвичайно рідко - знак чи клеймо поховального братства. Епітафії галицьких мацев виконані на івриті, спостерігається вплив їдишу у написанні імен, окремі фрагменти тексту могли бути виконані арамейською. Слід зазначити, що від XIX ст. на мацевах у зв'язку із асиміляційними процесами з'являється двомовність: ім'я, рідше окремі фрагменти тексту івритом дублюються німецькою або польською, рідко російською мовами. Розташовані після основного тексту на івриті або з тильного фасаду мацеви. Аналізуючи єврейську епітафію, задамося питанням, яке ж призначення мала епітафія? Чи $\epsilon$ складання надгробних текстів вимогою єврейської релігійної традиції? У Талмуді говориться про те, що місце поховання має бути зазначено, для чого над ним може бути встановлено надгробок, іменоване «нефеш» [11]. Надгробок встановлювався через рік після смерті. Так, наприклад, у Львові проектування, виготовлення та встановлення надгробка відбувалось згідно спеціальної Інструкції [4] та затверджувалось Комітетом 3 опіки над пам'ятками єврейського мистецтва при Правлінні єврейської релігійної громади міста. Стандартні короткі написи, що відрізняються лише іменами та датами, ймовірно, укладало похоронне братство або родичі померлого, ймовірно, заздалегідь сам померлий, а складні поетичні тексти складалися фахівцями на замовлення, мали відповідно індивідуальні особливості та були авторськими текстами. Це було можливим, оскільки в класичній галахічній літературі немає законів, що регламентують зміст текстів. У ряді випадків все ж відмічено факти абсолютно ідентичного дублювання навіть складних та поетичних текстів із зміненим іменем та датою.

Численні благословення роблять епітафію близькою до молитви, що підкреслюється закінченням деяких написів словом «амінь» (або характерним для псалмів і молитов завершенням «Амінь, амінь, амінь, Села, села, села!») і включенням в епітафії уривків 3 поминальних молитов «люблячі та близькі за життя i зі смертю не відокремлюються (розлучаються)» (3 молитви «Ав hа-Рахаман», в епітафії з Бучача, Печеніжина), і тим, що деякі епітафії кінця XIX століття 3 південно-східної Галичини - західної Буковини є поминальною молитвою «Ель мале Рахамім», що приводиться цілком, з доданим у потрібному місці імені похованого, так, що той, хто читає епітафію одночасно читає поминальну молитву. Крім поминальної молитви, епітафія має ряд рис, близьких оплакування померлого. В оплакуваннях, вимовлених під час похорону, про померлого йдеться в третій особі, вони цитують біблійні вислови й містять вихваляння покійного. Оплакування можуть містити месіанські мотиви - натяк на воскресіння мертвих в прийдешні часи, а їх мета змусити плакати читача, таким чином померлому буде надана честь [ 8 ].

Провідною епіграфічною тенденцією XVIII-XIX ст. було як введення померлого до біблійного контексту, так і фіксація його зв'язків з єврейською громадою. Таким чином, крім містичного сприяння заспокоєнню душі покійного, ще один мотив, чітко виявляється в єврейських епітафіях, - це возз'єднання душі покійного з спільністю душ народу Ізраїлю, в більш широкому сенсі - співвіднесення його особистості з єврейською історією та традицією. Найбільш характерним вираженням цієї тенденції є той факт, що невід'ємним елементом будь-якої епітафії стала заключна формула «Хай буде душа його (iii) зв'язана у в'язці живих». Ця формула, зазвичай у вигляді 
абревіатури, зберігається на івриті навіть якщо епітафія вже написана на іншій мові, таким чином вона стала символом еврейської епітафії.

Іншим способом співвіднесення $з$ єврейською традицією $є$ неявне зіставлення похованого 3 біблійними героями шляхом цитування Біблії. Більшість використовуваних в епітафіях стандартних формул і виразів так чи інакше сходять до Біблії, i їх вживання викликає асоціацію з відповідним біблійним персонажем або сюжетом. Дуже часто їх будували на вмілому цитуванні біблійного фрагмента, який має певне відношення до померлого. Важливо зазначити, що цитування в епіграфіці окремого некрополя практично не повторюється. Щоразу цитата майстерно обіграє конкретну ситуацію та ім'я покійного. Логічно припустити, що поховальне братство - організація, яка опікувалась кладовищем, - прискіпливо ставилося до складання та змісту тексту епітафії, який укладався окремо для кожної особи. Однак, слід зазначити, що іноді у текстах епітафій зустрічаються також: граматичні помилки - пропущена буква, знак; факти ідентичного дублювання складного, поетичного тексту на одному і тому ж кладовищі; випадки зумисного перекручування знаків у датуванні, оскільки вірно записана дата означала б слово із негативним контекстом, наприклад: брехати, вбивати; дата прихована у тексті.

Таким чином, ми бачимо, що функції епітафій визначають ії структурні елементи. Перераховані функції відображають уявлення юдеїв про безсмертя душі, іiї повернення до свого джерела «вузла життя», про сприйняття душею померлого того, що відбувається на землі, про майбутнє воскресіння мертвих після приходу Месії.

Наукова новизна полягає у тому, що вперше детально досліджено структуру традиційної єврейської епітафії, окреслено основні принципи побудови композиційних схем текстів епітафій, визначено їх значення та місце у композиційному вирішенні фасадів галицьких мацев. Окремі оригінальні представлені у статті тексти епітафій публікуються вперше.

Висновки. Автором проаналізовано структуру традиційної єврейської епітафії, описано іiі призначення, структуру та зміст. Виявлено, що функцію епітафії визначають ії структурні елементи. Запропоновано методику наукового опрацювання текстів різної складності та охарактеризовано їх зв'язок із символікою меморіальної пластики фасадів мацев. Визначено, що епітафії давніх юдейських кладовищ Східної Галичини XVI - першої третини XX ст. $є$ надзвичайно цінним

Переклад текстів: Андрій Корчак

\section{Jimepamypa}

1. Архів проекту: «Снятин - Археологія пам'яті: відкриття і привернення історичної та культурномистецької спадщини галицького містечка». Центр міської історії Центрально-Східної Європи у рамках програми «MEMORIA. Добровольці для збереження культурної спадщини Європи».

2. Бойко Х. «Снятин - Археологія пам'яті»: відкриття і повернення історичної та культурномистецької спадщини галицького містечка. Вісник Харківської державної академії дизайну і мистеитв. 2010. № 8. C.11-34.

3. Клименюк Т.М., Бойко Х.С. Архітектурні обміри та інвентаризація пам'ятників: навч. посіб. Львів: Вид-во Львівської політехніки, 2010. 176 с.

4. Кураторія опіки над пам'ятками єврейського мистецтва при Правлінні єврейської релігійної громади у м. Львові: Інструкція про правила виконання і встановлення надгробків на кладовищах. 1925-1928 рр. ЦДІА Украӥни у м. Львові. Ф. 701, Оп. 3. Спр. 713 - Арк.3.

5. Мартин М. Написи на предметах з колекції юдаїки ЛМІР. Вісник музею історії релігії. Львів, 2011. № 9. C. 67-72.

6. Носоновский М. Эпитафии XVI века с еврейских надгробий Украины. Памятники культуры. Новые открытия (Письменность, искусство, археология). Москва, 1999. С. 86-97.

7. Носоновский М. Еврейские эпиграфические пам'ятники Украины. Тирош. Труди второй молодежной конференции по иудаике. Москва, 1998. С.117-122.

8. Носоновский М. «Завязанные в к поетике еврейских эпитафий URL: http://berkovich-zametki.com/Nomer19/MN18.htm

9. Носоновский М. Об эпитафиях с еврейских надгробий Правобережной Украины. История евреев на Украине и в Белоруссии. - Санкт-Петербург, 1994. С. 107 - 119.

10. Ритуальне юдейське срібло з фондів Львівського музею історії релігії: каталог/ авт. - упоряд.: М. Мартин. Львів: Логос, 2018. 80 с.

11. Святе Письмо Старого та Нового Завіту: повний переклад, здійснений за оригінальними єврейськими, арамійськими та грецькими текстами. Ukrainian Bible 63 DC. United Bible Societies 1991- 60 M. П'ятикнижжя. С.3-177.

12. Хаймович Б. Историко-этнографические экспедиции Петербургского еврейского университета. История евреев на Украине и в Белоруссии. Санкт-Петербург, 1994. С. 15 - 43. 